\title{
Preparation and characterization of highly pure fractions of outer membrane, cytoplasmic and intracytoplasmic membranes from Ectothiorhodospira mobilis
}

\author{
Toni Ditandy and Johannes F. ImHoFF* \\ Institut für Mikrobiologie und Biotechnologie, Rheinische Friedrich-Wilhelms-Universität, Meckenheimer Allee 168, \\ D-5300 Bonn, Germany
}

(Received 2 June 1992; revised 7 September 1992; accepted 16 September 1992)

\begin{abstract}
Outer membrane (OM), cytoplasmic membrane (CM) and intracytoplasmic membranes (ICM) from the halophilic phototrophic purple sulphur bacterium Ectothiorhodospira mobilis 9903 were purified and characterized. The three membrane fractions were significantly different in regard to protein profiles on SDS-PAGE, and to the composition of amino acids, fatty acids and lipids. The presence of lipoproteins, the occurrence of lyso-phosphatidylethanolamine and an increased content of saturated and short-chain fatty acids are characteristic properties of the OM. CM and ICM fractions are different on the basis of buoyant density, of protein profiles and amino acid composition, and due to the presence of succinate dehydrogenase activity in $\mathrm{CM}$. In addition, $\mathrm{CM}$ and ICM showed significant differences in pigment content and absorption spectra.
\end{abstract}

\section{Introduction}

Successful separation of cellular membrane fractions is essential for all investigations aiming at understanding the processes of membrane differentiation. For this reason, and in order to understand the differentiation of ICM structures, numerous attempts have been made to purify the ICM of phototrophic purple bacteria and eventually also to separate it from the CM (Niederman, 1974; Niederman \& Gibson, 1978; Garcia \& Drews, 1980; Drews \& Oelze, 1981; Kaufmann et al., 1982).

A number of investigations have dealt with the purification of 'chromatophores' of phototrophically grown cells of Rhodobacter capsulatus (Garcia \& Drews, 1980; Kaufmann et al., 1982), Rhodobacter sphaeroides (Niederman, 1974), Rhodospirillum rubrum (Collins \& Niederman, 1976) and Chromatium vinosum (Hurlbert et al., 1974). In most of these cases, OM or cell envelope fractions were obtained that were contaminated with ICM. Similarly, CM fractions were obtained that were contaminated with $\mathrm{OM}$ and with significant amounts of ICM. Much effort has been made to purify membrane fractions from $R b$. sphaeroides. Niederman et al. (1979)

* Author for correspondence. Tel. 228 737719; fax 228737576.

Abbreviations: OM outer membrane; CM cytoplasmic membrane; ICM intracytoplasmic membrane; BChl bacteriochlorophyll; LH I antenna complex I; LH II antenna complex II; RC reaction centre; $\mathrm{SDH}$, succinate dehydrogenase. were the first to obtain an upper pigmented fraction in addition to the usual chromatophore fraction from phototrophically grown $R b$. sphaeroides. These authors interpreted the presence of part of the photosynthetic apparatus in the presumed $\mathrm{CM}$ fraction as initiation sites of ICM formation. Membrane vesicles from phototrophically grown $R b$. sphaeroides cells have also been isolated on a sucrose density gradient after prior removal of OM and osmotic shock of spheroplasts (Picorel et al., 1990), but purification of OM and ICM was not attempted in this case. The ICM was found as a heavy fraction at $40 \%(\mathrm{w} / \mathrm{v})$ sucrose. Comparable methods for the isolation of chromatophores or spheroplast-derived vesicles from the same bacterium were also used by Takemoto \& Bachmann (1979) and by Hellingwerf et al. (1975).

In order to avoid cross-contamination with ICM, CM fractions have been isolated from chemotrophically grown purple bacteria ( $R$. rubrum and $R b$. sphaeroides; Oelze et al., 1975; Guillotin \& Reiss-Husson, 1975; Collins \& Niederman, 1976). As an example, two different membrane fractions were isolated from aerobically grown $R$. rubrum cells (Oelze $e t$ al., 1975; Collins $\&$ Niederman, 1976). The CM was found at the top of the sucrose density gradient at about $30 \%(\mathrm{w} / \mathrm{v})$, the $\mathrm{OM}$ fraction at about $50 \%(\mathrm{w} / \mathrm{v})$ sucrose. The lack of ICM under these growth conditions facilitates the purification of CM. It is not possible, however, to obtain information on differentiation processes under photo- 
trophic growth conditions from analysis of membranes from chemotrophically grown cells.

In the present communication, we report on a procedure to obtain different membrane fractions of Ectothiorhodospira mobilis 9903 . Highly pure fractions of $\mathrm{OM}, \mathrm{CM}$ and ICM from phototrophically grown cells were characterized and structural differences in the photosynthetic apparatus in CM and ICM fractions are indicated.

\section{Methods}

Strains and culture conditions. Ectothiorhodospira mobilis strain BN 9903 is an isolate from alkaline soda lakes of the Wadi Natrun in Egypt (Imhoff et al., 1979, 1991). Cells were grown in $50 \mathrm{ml}$ and 1 litre screwcap bottles on the medium described by Imhoff (1988) containing 5\% $(\mathrm{w} / \mathrm{v})$ total salts. Cells were incubated at $42{ }^{\circ} \mathrm{C}$ with an illumination of 20000-25000 lux.

Preparation of cell fractions. Cells were harvested in the lateexponential growth phase by centrifugation at $11000 \mathrm{~g}$. The collected cell pellets were washed in $50 \mathrm{~mm}$-Tris/ $\mathrm{HCl} \mathrm{pH} 9$ containing $5 \%(\mathrm{w} / \mathrm{v})$ $\mathrm{NaCl}$ and resuspended in the same buffer plus $30 \%(\mathrm{w} / \mathrm{v})$ sucrose in one-tenth of the culture volume. Mureinoplasts were collected by renewed centrifugation. The supernatant was dialysed and recentrifuged at $200000 \mathrm{~g}$ to harvest the OM. The supernatant contained the soluble periplasmic proteins.

Mureinoplasts were resuspended and incubated for $3 \mathrm{~h}$ in Tris $/ \mathrm{HCl}$ $\mathrm{pH} 9$ with $0.5 \mathrm{mg}$ lysozyme $\mathrm{ml}^{-1}$. This procedure yielded protoplasts, which were washed in Tris/ $\mathrm{HCl} \mathrm{pH} \mathrm{9,} \mathrm{incubated} \mathrm{for} 30 \mathrm{~min}$ in $6 \mathrm{M}$ glycerol, $5 \mu \mathrm{g}$ DNAase $\mathrm{ml}^{-1}, 1 \mu \mathrm{g}$ RNAase $\mathrm{ml}^{-1}$, and broken by osmotic shock by very rapidly adding 10 vols distilled water. The red supernatant from a low-speed centrifugation was further separated on a sucrose density gradient $(20-60 \%, w / v)$ into two pigmented bands.

Protein determination. Protein was determined by the Lowry method. Pigments were extracted with ice-cold acetone/methanol $(7: 2, \mathrm{v} / \mathrm{v})$. The pigment-free protein was collected by centrifugation, dried and used for protein assay. Bovine serum albumin served as a standard.

Analysis of pigments. Absorption spectra were measured with a Perkin-Elmer Lambda 2 double beam spectrophotometer using $1 \mathrm{~cm}$ quartz cuvettes. Membrane fractions were suspended in $50 \mathrm{~mm}$-Tris/ $\mathrm{HCl} \mathrm{pH} 9$ containing $60 \%(\mathrm{w} / \mathrm{v})$ sucrose.

For the determination of bacteriochlorophyll $a(\operatorname{Bchl} a), 0.05 \mathrm{ml} 1 \mathrm{M}$ Tris $/ \mathrm{HCl} \mathrm{pH} 8$ was added to a $0.5 \mathrm{ml}$ sample. This mixture was extracted with $4.5 \mathrm{ml}$ acetone/methanol $(7: 2, \mathrm{v} / \mathrm{v})$ for $30 \mathrm{~min}$ in the dark at $4{ }^{\circ} \mathrm{C}$. The sample was centrifuged and the supernatant made up to $5 \mathrm{ml}$. Concentrations of Bchl $a$ were calculated from the absorbance at $775 \mathrm{~nm}$ in acetone/methanol extracts by using $\varepsilon=82 \cdot 3 \mathrm{M}^{-1} \mathrm{~cm}^{-1}$ (Clayton, 1963).

For characterization of carotenoids, membrane fractions were extracted with acetone/methanol $(7 / 2, \mathrm{v} / \mathrm{v})$. Insoluble material was removed by centrifugation. This procedure was repeated until the supernatant was colourless. The total volume was adjusted to $0.5 \mathrm{ml}$. Pigments were separated by thin-layer chromatography on Sil G-50 plates (Macherey and Nagel, Düren, FRG). To prevent oxidation of the carotenoids during chromatography, plates were pretreated with sodium ascorbate and Livio plant oil. Samples and plates were always kept in the dark. Light petroleum (b.p. $60-80^{\circ} \mathrm{C}$ )/propan-2-ol/water (100:12:0.25, by vol.) was used as solvent system. Reference strains with known carotenoids were used for identification of the pigment bands.

Amino acid analysis. Samples containing about $1 \mathrm{mg}$ protein were dried and redissolved in $0.5 \mathrm{ml} 6 \mathrm{M} \mathrm{HCl}$ containing $0.05 \%$ dithio- erythritol. Proteins were hydrolysed in sealed tubes at $115^{\circ} \mathrm{C}$ for $18 \mathrm{~h}$ under vacuum conditions. After hydrolysis the tubes were opened. dried in vacuum over $\mathrm{KOH}$, and the contents redissolved in distilled water in order to remove the $\mathrm{HCl}$ completely. This procedure was repeated three times. The dried samples were finally dissolved in $3 \mathrm{ml}$ sodium borate buffer $(0 \cdot 4 \mathrm{M}, \mathrm{pH} 9 \cdot 5)$. Amino acids were analysed after derivatization with $o$-phthaldialdehyde (OPA), as described by Sahl $e t$ al. (1985). Borate buffer $(10 \mathrm{ml})$ was added to a $10 \mu \mathrm{l}$ sample and $20 \mu \mathrm{l}$ of this diluted solution was derivatized with $80 \mu \mathrm{l}$ of OPA reagent. This reagent was kept as a stock solution of $56 \mathrm{mg}$ OPA in $1 \mathrm{ml}$ methanol and $10 \mu \mathrm{l} 2$-mercaptoethanol. For use, a tenfold dilution in borate buffer was prepared each day. After derivatization for $1 \mathrm{~min}$, a $20 \mu \mathrm{l}$ portion was injected onto a reversed phase C-18 column (HypersilODS-5). Separation was achieved by using a gradient of 20-100\% methanol containing $3 \%(\mathrm{v} / \mathrm{v})$ tetrahydrofuran and $50 \mathrm{~mm}$-sodium phosphate buffer $\mathrm{pH} 6.5$. The OPA derivatives of the amino acids were detected with a Shimadzu fluorospectrophotometer equipped with a flow-through cell. Excitation and emission wavelengths were $340 \mathrm{~nm}$ and $450 \mathrm{~nm}$, respectively. For quantitative evaluation, the peak areas were calibrated daily with a standard mixture containing $100 \mathrm{pmol}$ of each amino acid. With this method, 15 different amino acids were detected.

Determination of phospholipid content. Phospholipids were extracted by the method of Bligh \& Dyer (1959). The total phosphate content was determined by the method of Chen et al. (1956). Dried $\mathrm{KH}_{2} \mathrm{PO}_{4}$ was used as a standard. The total phospholipid content was calculated by assuming that $1 \mathrm{nmol}$ phosphate corresponds to $84.7 \mathrm{ng}$ phospholipid, and that the average molecular weight of the phospholipids is 800 (Bligh \& Dyer, 1959).

Succinate dehydrogenase (EC 1.3.99.1) assay. The method of King (1963) and King \& Drews (1973) was used. The reduction of 2,6dichlorophenolindophenol at $600 \mathrm{~nm}$ mediated by phenazine methosulphate was measured. The reaction mixture contained $6 \mathrm{~mm}$-sodium succinate, $4 \mathrm{~mm}$-sodium azide, $0.04 \mathrm{~mm}$-phosphate buffer $\mathrm{pH} 7.5$. $0.06 \mathrm{~mm}$-2,6-dichlorophenolindophenol and $0.4 \mathrm{~mm}$ phenazine methosulphate. The absorbance change was measured over a period of $15 \mathrm{~min}$.

$S D S-P A G E$. Polyacrylamide gels were prepared according to the method of Laemmli (1970), with acrylamide concentrations of $10 \%$ and $15 \%(\mathrm{w} / \mathrm{v})$.

Other methods. Fatty acids and lipids were analysed by procedures described previously (Imhoff, 1991; Imhoff \& Thiemann, 1991). For staining proteolipids and lipoproteins in SDS-PAGE we used the method of Baumgardner et al. (1980). DNA and RNA determinations were made with orcin and diphenylamine as reagents according to Holtzhauer (1989). Antenna polypeptides of the membranes were isolated according to Brunisholz et al. (1984).

\section{Results}

\section{Purification of $O M, C M$ and ICM}

In order to avoid cross-contamination between $\mathrm{OM}$ and other membrane fractions, we removed the $\mathrm{OM}$ of Ectothiorhodospira mobilis by treatment with $30 \%(\mathrm{w} / \mathrm{v})$ sucrose prior to cell breakage. After separation from the mureinoplasts, high-speed centrifugation yielded an OM fraction that was free of photosynthetic pigments. The $\mathrm{OM}$ had a yellowish translucent, gel-like consistency, similar to an $\mathrm{OM}$ fraction from $R b$. sphaeroides (Evers $e t$ al., 1984). The mixture of CM and ICM, obtained after 
lysozyme treatment, glycerol incubation and osmotic shock of the protoplasts, was separated on a $20-60 \%$ sucrose gradient. After successful osmotic shock, we obtained two coloured bands in the sucrose density gradients. The $\mathrm{CM}$ fraction was found at $30 \%$ sucrose $\left(1.12 \mathrm{~g} \mathrm{~cm}^{-3}\right)$ and the ICM fraction at about $50 \%$ sucrose $\left(1.23 \mathrm{~g} \mathrm{~cm}^{-3}\right)$.

The high purity of the membrane fractions obtained is demonstrated by the following observations. (i) All three membrane fractions were free of contamination by ribosomes and nucleic acids, as is indicated by absorption ratios $\left(A_{260} / A_{280}\right)$ that were always less than $1 \cdot 0$. Also, chemical analyses with orcin and diphenylamine (Holtzhauer, 1989) did not give any indication of contamination of these fractions by DNA and RNA. The DNA/RNA content was always lower than $2 \mu \mathrm{g}$ (mg protein) ${ }^{-1}$. (ii) Succinate dehydrogenase activity (SDH) was nearly exclusively found in the $\mathrm{CM}$ fraction. It was completely absent in the OM fraction. Specific activity of SDH was $2.2 \pm 0.6 \mathrm{nmol} \mathrm{min}^{-1}(\mathrm{mg} \text { protein })^{-1}$ in the CM fraction and $0.028 \pm 0.009 \mathrm{nmol} \mathrm{min}^{-1}$ (mg protein) ${ }^{-1}$ in the ICM fraction. (iii) Two bands, staining with Solvent Black 3, were detected after SDS-PAGE of OM fraction proteins. This reagent is used for specific detection of proteolipids and lipoproteins in SDS-polyacrylamide gels (Baumgardner et al., 1980). The other two membrane fractions did not contain proteins staining with Solvent Black 3. (iv) Electron microscopy showed that the CM and ICM fractions were visually quite different (data not shown). Membranes of the ICM fraction had a distinct discshape, while those of the $\mathrm{CM}$ were irregular in form and size and often appeared as small vesicles. The former had a higher electron density than the latter fraction.

\section{Absorption spectra and pigments}

Remarkable differences were found in the absorption spectra (Fig. 1) and the pigment content of OM, CM and ICM fractions. Absorption maxima indicative of the presence of carotenoids, Bchl $a$ and various forms of Bchl-protein complexes were absent from the OM fraction. Such absorption maxima were most pronounced in the ICM fraction. Absorption spectra of this fraction showed maxima at $800 \mathrm{~nm}$ and $850 \mathrm{~nm}$ characteristic of antenna complexes II (LH II) and of antenna complexes I (LH I) at $890 \mathrm{~nm}$. Those of pure CM fractions indicated the presence only of the reaction centre (RC) and LH I complexes with maxima at $800 \mathrm{~nm}$ and $890 \mathrm{~nm}$ (Fig. 1).

Although both CM and ICM contained photosynthetic pigments, they showed significant differences in their qualitative and quantitative pigment content. At identical protein concentrations, the $\mathrm{CM}$ had a pink and the ICM a deep red colour. The amount of Bchl $a$ in
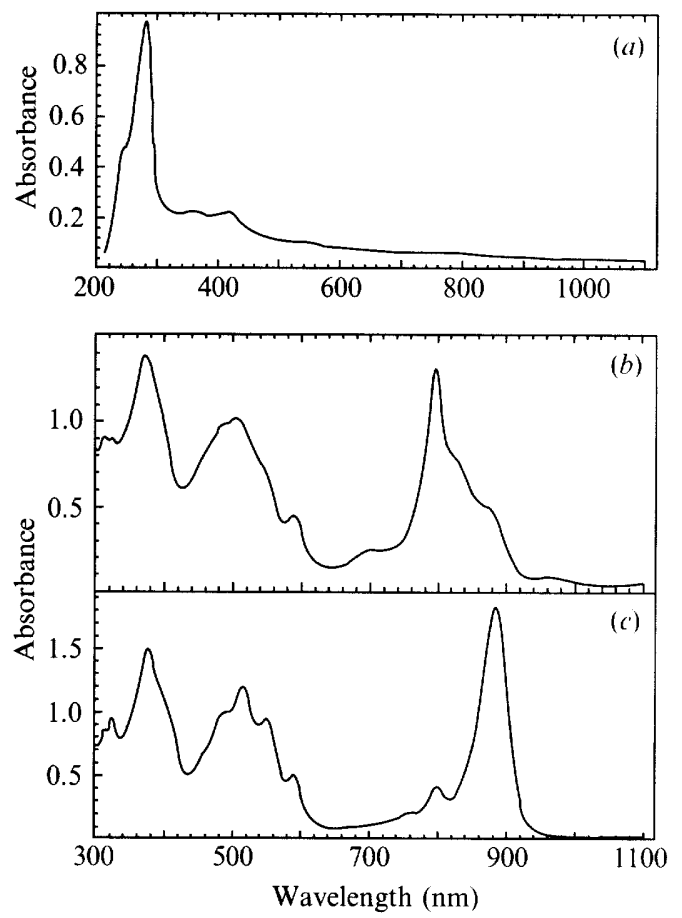

Fig. 1. Absorption spectra of purified OM (a), ICM (b) and CM (c) from E. mobilis 9903 grown at $5 \%$ total salts.

Table 1. Phospholipid and BChl a content of OM, CM and ICM from E. mobilis 9903

\begin{tabular}{lcc}
\hline \hline Fraction & $\begin{array}{c}\text { BChl } a \text { concentration } \\
{\left[\mu \mathrm{g}(\mathrm{mg} \text { protein })^{-1}\right]}\end{array}$ & $\begin{array}{c}\text { Phospholipid content* } \\
\left.[\mathrm{mg} \mathrm{(mg} \mathrm{protein})^{-1}\right]\end{array}$ \\
\hline OM & Not detected & 2.56 \\
CM & 7.76 & 0.85 \\
ICM & 91.79 & 0.71 \\
\hline \hline
\end{tabular}

* On the basis of the phosphate content of solvent-soluble lipids, calculated by the method of Chen et al. (1956).

the ICM was $92 \mu \mathrm{g}$ (mg protein) $)^{-1}$ compared to $8 \mu \mathrm{g}$ (mg protein) $^{-1}$ in the CM (Table 1). Differences in pigment composition were also demonstrated by separating the carotenoids on TLC plates (data not shown). Spirilloxanthin was the major component in the ICM, besides lower contents of lycopene, rhodopin and rhodovibrin. In the $\mathrm{CM}$ fraction only spirilloxanthin was found, even in highly concentrated pigment fractions.

\section{Protein profiles}

Protein profiles of the three membrane fractions showed an individual and characteristic pattern (Fig. 2). The OM had four main polypeptide bands with $M_{\mathrm{r}}$ values of about $8000,18000,19000$ and 26000 . Two of these protein bands, with $M_{\mathrm{r}}$ values of about 8000 and 26000 , also stained with Solvent Black 3. The ICM had five clearly dominating major polypeptide bands. These 


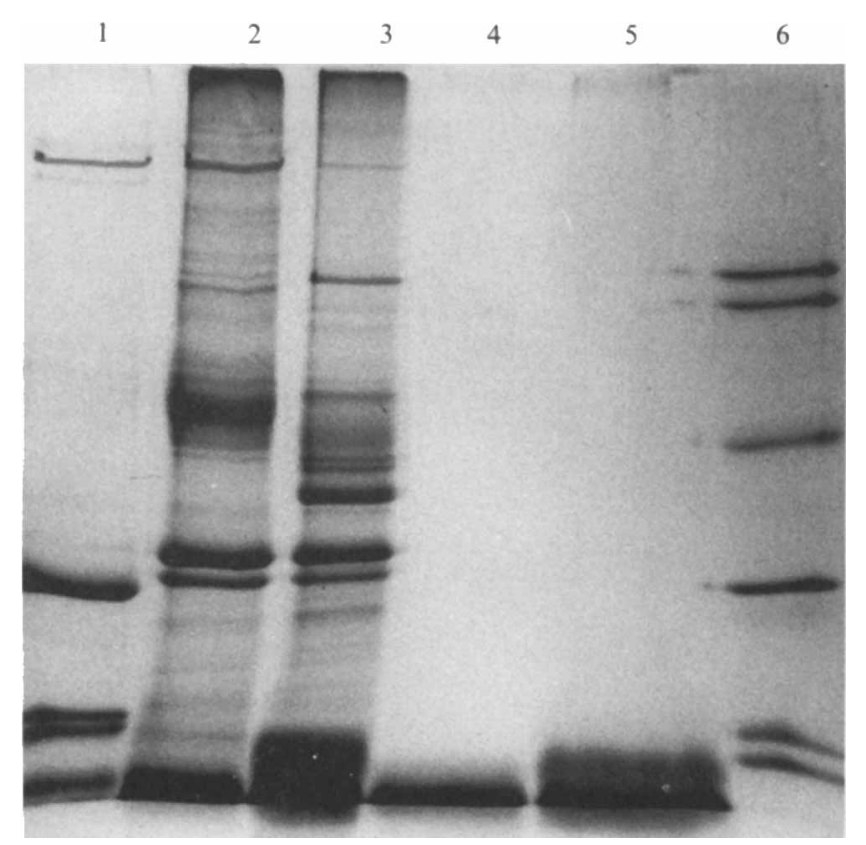

Fig. 2. SDS-PAGE (polyacrylamide concn $15 \% \mathrm{w} / \mathrm{v}$ ) of OM (lane 1), CM (2) and ICM (3) fractions of E. mobilis 9903 grown on $5 \%$ total salts. Antenna polypeptides of CM (lane 4) and of ICM (5) are also shown. Lane 6, standard proteins: cytochrome $c, M_{\mathrm{r}} 12300$; myoglobin, 17200; carbonic anhydrase, 30000; ovalbumin, 43000; albumin, 66250; ovotransferrin, 76-78000.

bands were present in solubilized and purified $\mathrm{RC} / \mathrm{LH} \mathrm{I}$ and $\mathrm{RC} / \mathrm{LH} \mathrm{I} / \mathrm{LH}$ II complexes from these membrane fractions (unpublished results) and therefore can be regarded as constituents of the photosynthetic apparatus. Bands of $M_{\mathrm{r}} 7000$ and 12000 were characteristic of $\mathrm{LH}$ I and LH II respectively. Bands of $M_{\mathrm{r}} 31000,33000$ and 37000 were constituents of the RCs of the photosynthetic apparatus. Polypeptides with $M_{\mathrm{r}}$ values greater than 70000 were not seen in the ICM fraction; they were characteristic, however, for the CM fraction, which contained a number of such polypeptides. Four polypeptides with $M_{\mathrm{r}}$ values of about $7000,31000,33000$ and a broad band at about 47000 were quantitatively dominant in the CM. The last band was typical for this fraction. The antenna polypeptides of LH II of $M_{\mathrm{r}} 12000$ and the band of $M_{\mathrm{r}} 37000$, both major bands in the ICM, were absent in pure $\mathrm{CM}$ fractions. The isolation of antenna polypeptides from purified CM and ICM according to Brunisholz et al. (1984) supported differences in the composition of antenna complexes in those two membrane fractions (Fig. 2).

\section{Amino acid composition}

As with the protein composition, the amino acid composition of the three membrane fractions also revealed characteristic differences (Table 2). Asp, Ala
Table 2. Amino acid composition of proteins from $O M$, $C M$, and ICM of E. mobilis 9903

Values are percentages of the total amount of amino acids.

\begin{tabular}{lrrr}
\hline $\begin{array}{c}\text { Amino } \\
\text { acid }\end{array}$ & OM & CM & ICM \\
\hline Asp & $15 \cdot 9$ & $10 \cdot 9$ & $12 \cdot 5$ \\
Glu & $13 \cdot 6$ & $14 \cdot 4$ & $16 \cdot 5$ \\
Ser & $11 \cdot 3$ & $7 \cdot 9$ & $7 \cdot 6$ \\
His & $2 \cdot 6$ & $1 \cdot 5$ & $2 \cdot 3$ \\
Thr & $5 \cdot 8$ & $7 \cdot 2$ & $3 \cdot 6$ \\
Gly & $0 \cdot 9$ & $4 \cdot 1$ & $3 \cdot 4$ \\
Arg & $5 \cdot 9$ & $5 \cdot 3$ & $5 \cdot 8$ \\
Ala & $10 \cdot 5$ & $10 \cdot 9$ & $12 \cdot 6$ \\
Tyr & $4 \cdot 5$ & $13 \cdot 5$ & $4 \cdot 8$ \\
Met & $2 \cdot 8$ & $3 \cdot 9$ & $4 \cdot 3$ \\
Val & $9 \cdot 1$ & $4 \cdot 6$ & $4 \cdot 8$ \\
Phe & $3 \cdot 2$ & $6 \cdot 5$ & $5 \cdot 9$ \\
Ile & $2 \cdot 8$ & $4 \cdot 8$ & $4 \cdot 1$ \\
Leu & $5 \cdot 2$ & 1.5 & $7 \cdot 6$ \\
Lys & $5 \cdot 9$ & 3.0 & $4 \cdot 4$ \\
\hline \hline
\end{tabular}

and Glu were dominant in all membrane fractions. Characteristic was the high amount of Tyr $(13.5 \%)$ in the $\mathrm{CM}$ and the high content of Glu and the low content of Thr in the ICM. Compared to the other membrane fractions, the OM had a higher content of Ser and Val, but a lower content of Gly and Ile.

A general property of proteins is determined by the polarity of their amino acids. This property may be expressed as the average hydrophobicity (Bigelow, 1967) or as the content of polar, intermediate and non-polar amino acids (Vanderkoi \& Capaldi, 1972). Application of these parameters to the bulk proteins of our membrane fractions revealed significant differences. The average hydrophobicity of OM was $365 \mathrm{~kJ}$ per residue, of $\mathrm{CM}$ $445 \mathrm{~kJ}$ per residue and of ICM $397 \mathrm{~kJ}$ per residue. The content of polar amino acids amounted to $41.3 \%$ in OM, $33.6 \%$ in CM and $39.2 \%$ in ICM. Also different were the values of intermediate amino acids (OM 25.1\%, CM $34.2 \%$, ICM $21.5 \%$ ) and non-polar amino acids (OM $33.6 \%$, CM $32.2 \%$, ICM $39.2 \%$ ). Quite remarkable differences were also found between CM and ICM, not only in the relative content of individual amino acids, but also regarding the average hydrophobicity and proportions of polar and non-polar amino acids.

\section{Lipids and fatty acids}

No significant qualitative or quantitative differences in the polar lipid composition of CM and ICM were found in two-dimensional thin-layer chromatography separations (data not shown). The OM, however, had a higher content of cardiolipin and a lower one of phosphatidic acid. Lyso-phosphatidylethanolamine was detectable in the OM only (data not shown). 
Table 3. Fatty acid composition of membrane fractions from E. mobilis 9903

Values are percentages of the total amount of fatty acids. ND, Not detected.

\begin{tabular}{|c|c|c|c|}
\hline $\begin{array}{c}\text { Fatty } \\
\text { acid }\end{array}$ & $\mathrm{OM}$ & $\mathrm{CM}$ & $\mathrm{ICM}$ \\
\hline C 12:0 & $0 \cdot 3$ & ND & ND \\
\hline C $14: 0$ & $2 \cdot 4$ & 0.2 & 0.6 \\
\hline C $14: 1$ & 0.4 & ND & 0.9 \\
\hline C 16:0 & $27 \cdot 1$ & $23 \cdot 8$ & $23 \cdot 2$ \\
\hline C $16: 1$ & $2 \cdot 9$ & $3 \cdot 2$ & $1 \cdot 7$ \\
\hline C 18:0 & $14 \cdot 2$ & 11.6 & $10 \cdot 9$ \\
\hline C $18: 1$ & $45 \cdot 2$ & $56 \cdot 8$ & $57 \cdot 5$ \\
\hline C 19 cyc & $2 \cdot 6$ & 1.9 & $2 \cdot 9$ \\
\hline C $20: 0$ & $1 \cdot 5$ & 0.4 & 0.4 \\
\hline Sum of C 16 & $30 \cdot 0$ & $27 \cdot 0$ & $24 \cdot 9$ \\
\hline Sum of C 18 & $59 \cdot 4$ & $68 \cdot 4$ & $68 \cdot 4$ \\
\hline Sum of sat. & $45 \cdot 5$ & $36 \cdot 0$ & $35 \cdot 1$ \\
\hline Sum of unsat.* & $51 \cdot 1$ & $61 \cdot 9$ & $63 \cdot 0$ \\
\hline
\end{tabular}

* 19 cyc included.

The content of fatty acids in solvent-extractable lipids from OM, CM and ICM is shown in Table 3. Although all membrane fractions had $\mathrm{C} 18: 1$ as the dominant fatty acid, its content was significantly lower in the $\mathrm{OM}$ $(45 \cdot 2 \%)$ compared to the two other membrane fractions. The $\mathrm{C} 18: 1$ content of the $\mathrm{CM}$ was $56.8 \%$ and that of the ICM $57.5 \%$. A significantly higher content of shortchain and saturated fatty acids was characteristic for the OM. Major differences between CM and ICM are represented by the higher content of $\mathrm{C} 16$ and the lower one of $\mathrm{C} 14$ fatty acids in the CM.

\section{Discussion}

Numerous reports deal with the purification of ICMs of different phototrophic purple bacteria. In almost all investigations, methods for membrane separations involved harsh treatments such as French pressure cell passage or ultrasonication to disrupt cells and membranes. Various numbers of membrane fractions were obtained, which were classified as chromatophores, CM, OM or cell envelopes.

Five membrane fractions, for example, were collected from a sucrose gradient of $C$. vinosum cells disrupted by sonication (Hurlbert et al., 1974). The uppermost three fractions, called 'light fractions', were deep red in colour. There was no decisive difference in the composition of these three membrane fractions, which all contained RCs and antenna complexes, a typical property of chromatophores. Fractions four and five, the 'heavy fractions', were light pink and turbid. They were regarded as mixtures of $\mathrm{OM}$ and $\mathrm{CM}$. After French pressure cell disruption and sucrose gradient centri- fugation, five membrane bands were also obtained from $R b$. capsulatus (Kaufmann et al., 1982). In this case the heavy fraction was characterized as chromatophores. All membrane fractions contained $\mathrm{RC}$ and antenna complex I polypeptides, whereas polypeptides of the antenna complex II were dominant in the heavy membrane fraction. Only three membrane fractions were found in another investigation with $R b$. capsulatus (Garcia \& Drews, 1980). The heavy fraction was characterized as the chromatophore fraction, although a clean separation of OM, CM and ICM was not obtained. SDH activity in the light fraction banding at $28-36 \%$ sucrose was higher than in the other membrane fractions, although activity was present in all fractions. Pure CM of $R b$. capsulatus obtained from chemotrophically grown cells represented a light fraction $\left(1.139 \mathrm{~g} \mathrm{~cm}^{-3}\right)$ on sucrose gradients (Flammann \& Weckesser, 1984). Fractions of CM from phototrophically grown cells have not been successfully purified and characterized. An ICM fraction from $E$. mobilis also was obtained by the sequential treatment of the cells with lysozyme, osmotic shock and differential centrifugation (Oyewole \& Holt, 1976). Attempts to purify $\mathrm{OM}$ and $\mathrm{CM}$ and to analyse differences in the membrane fractions were not made.

Because all attempts to obtain fractions of $\mathrm{CM}$ and ICM after cell breakage by sonication or French press yielded several bands in sucrose density gradients and resulted in membrane fractions that showed significant cross-contamination of their protein bands, we broke cells by osmotic shock and developed the presented method for preparation of membrane fractions. Several lines of evidence indicate that our membrane fractions of $\mathrm{OM}, \mathrm{CM}$ and ICM are highly pure.

(i) $\mathrm{SDH}$ activity is specifically associated with the $\mathrm{CM}$ of E. mobilis 9903 . The activity in the ICM fraction was only about $1 \%$ of that in the CM fraction. The specific activity of SDH $\left[2.2 \mathrm{nmol} \mathrm{m^{-1 }}\right.$ (mg protein) $\left.{ }^{-1}\right]$ in the $\mathrm{CM}$ fraction is comparable to those in the $\mathrm{CM}$ fractions of Chloroflexus aurantiacus (Feick et al., 1982;

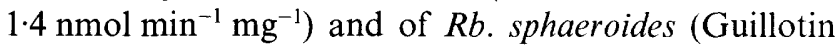
\& Reiss-Husson, $1975 ; 4 \cdot 7 \mathrm{nmol} \mathrm{min}^{-1} \mathrm{mg}^{-1}$ ). Compared to values for $R$. rubrum (Oelze et al., 1975; $39 \mu \mathrm{mol} \mathrm{min}^{-1} \mathrm{mg}^{-1}$ ) and $R b$. capsulatus (Flammann \& Weckesser, $1984 ; 0 \cdot 3 \mu \mathrm{mol} \mathrm{min}^{-1} \mathrm{mg}^{-1}$ ), however, this activity is very low.

(ii) Each membrane fraction has a typical protein profile in SDS-PAGE. Major bands of OM were not detectable in CM and ICM. In addition, characteristic major protein bands of $\mathrm{CM}$ and ICM could not be detected in the other membrane fractions. This indicates lack of cross-contamination of the three membrane fractions. The main protein bands of ICM were those of the antenna complexes, with $M_{\mathrm{r}}$ values of about 7000 and 12000 , and of the RC at 31000,33000 and 37000 . 
These values compare to $M_{\mathrm{r}}$ values of 24800,31300 , 33000 and 36600 for the $\mathrm{L}, \mathrm{M}$ and $\mathrm{H} \mathrm{RC}$ subunits and a cytochrome of an unidentified Ectothiorhodospira species (Lefebvre et al., 1989), and to $M_{\mathrm{r}}$ values of 26500 , 34000 and 35000 for RC subunits from E. mobilis, $E$. shaposhnikovii and E. halophila (Leguijt \& Hellingwerf, 1991).

(iii) The presence of lyso-phosphatidylethanolamine and bands staining with Solvent Black 3 in SDSpolyacrylamide gels is characteristic for the $\mathrm{OM}$ fraction. Lack of detectable quantities of these compounds in $\mathrm{CM}$ and ICM proves that the latter two are free of contamination with OM. Lyso-phosphatidylethanolamine was also found as a characteristic compound of the OM fraction of $R$. rubrum (Oelze et al., 1975).

(iv) The absence of pigments in the OM demonstrates absence of contamination by CM and in particular ICM in this membrane fraction.

(v) $\mathrm{CM}$ and ICM have different absorption spectra and differences in pigment-protein complex composition. LH II complexes were found only in the ICM fraction. R. A. Niederman and co-workers were the first to obtain an upper pigmented membrane fraction different from the usual light fractions of $R b$. sphaeroides. Although these authors used a French pressure cell to break the cells and did not remove the OM prior to breaking the cells, they were able to demonstrate that the pigment complexes of their upper band moved into ICM during further membrane development (Inamine et al., 1984; Reilly \& Niederman, 1986). They called the locations of the CM containing these pigment-protein complexes initiation sites of ICM development. The presence of such sites in the CM of E. mobilis could explain the presence of pigment-protein complexes in our CM fraction. LH II was found only in the ICM fraction and apparently is incorporated only in the developed or developing ICM. If we assume that LH II complexes are specifically inserted into the ICM only and that $\mathrm{RC} / \mathrm{LH}$ I complexes are additionally located in the $\mathrm{CM}$ at so-called initiation sites of ICM invagination, then lack of LH II in CM fractions demonstrates lack of contamination by ICM and high purity of this membrane fraction. During osmotic shock, the presumed initiation sites remain attached to the CM.

ICM fractions of E. mobilis 9903 (this study) and $E$. mobilis 8113 (Oyewole \& Holt, 1976) showed significant differences in their composition. Other membrane fractions were not characterized by Oyewole \& Holt (1976).

Although the Bchl $a$ content in the ICM fractions of $E$. mobilis 9903 and E. mobilis 8113 is nearly identical [92 and $85 \mu \mathrm{g}$ (mg protein) ${ }^{-1}$, respectively], differences between our results on ICM composition and the results of Oyewole \& Holt (1976) are to be expected, because different strains were used in the two studies. Observed differences also may be due to differences in growth conditions and growth phase of the cells investigated. We used cells from the exponential growth phase and grown at $42{ }^{\circ} \mathrm{C}$ compared to cells of E. mobilis 8113 from stationary growth phase and grown at $29^{\circ} \mathrm{C}$. The different growth conditions may be one important reason for differences in fatty acid compositions. It is known that fatty acid composition is strongly dependent on growth temperature and salinity, and that the proportion of 19 cyc increases towards the stationary phase at the expense of 18:1 (Imhoff \& Thiemann, 1991). This explains the considerably higher content of $19 \mathrm{cyc}$ $(25.5 \%)$ in E. mobilis 8113 compared to our results $(2.9 \%)$. The fatty acid composition of the isolated ICM fraction from E. mobilis 9903 is quite similar to that of whole membrane fractions of this strain grown at the same temperature (Imhoff \& Thiemann, 1991). This can be expected, as the ICM represents the major part of the whole membrane fraction of E. mobilis.

Differences in the fatty acid composition between $\mathrm{CM}$ and OM of E. mobilis 9903 were similar to those found in other purple bacteria. A higher content of short-chain and saturated fatty acids and a reduced content of C 18:1 was also found in the OM fraction of $R$. rubrum (Oelze et al., 1975). Similar trends were also found in $R b$. capsulatus (Flammann \& Weckesser, 1984) and $C$. vinosum (Hurlbert et al., 1974). It is concluded that this indicates a general phenomenon among Gram-negative bacteria.

Part of this work was supported by the DFG. HPLC analyses were made in the Institut für Mikrobiologie und Immunologie, BonnVenusberg; we thank Professor Dr H. G. Sahl for his advice during these analyses and for making his HPLC facilities available for this study.

\section{References}

Baumgardner, D., Deal, C. \& Kaplan, S. (1980). Protein composition of Rhodopseudomonas sphaeroides outer membrane. Journal of Bacteriology 143, 265-273.

BigeLow, C. C. (1967). On the average hydrophobicity of proteins and the relation between it and protein structure. Journal of Theoretical Biology 16, 187-211.

Bligh, E. G. \& DYER, W. J. (1959). A rapid method of total lipid extraction and purification. Canadian Journal of Biochemistry and Physiology 37, 911-917.

BRUNisholz, R. A., SUTER, F. \& ZUBER, H. (1984). The light harvesting polypeptides of Rhodospirillum rubrum. Hoppe-Seyler's Zeitschrift für physiologische Chemie 365, 675-688.

Chen, P. S., Toribara, T. Y. \& Warner, H. (1956). Microdetermination of phosphorus. Analytical Chemistry 28, 1756-1758.

Clayton, R. K. (1963). Towards the isolation of a photochemical reaction center in Rhodopseudomonas sphaeroides. Biochemica et Biophysica Acta 75, 312-323.

Collins, M. L. P. \& Niederman, R. A. (1976). Membranes of Rhodospirillum rubrum: isolation and physicochemical properties of membranes from aerobically grown cells. Journal of Bacteriology 126, 1316-1325.

Drews, G. \& Oelze, J. (1981). Organization and differentiation of membranes of phototrophic bacteria. Advances in Microbial Physiology $1-85$. 
Evers, D., Weckesser, J. \& Drews, G. (1984). Protein on the cell surface of the moderately halophilic phototrophic bacterium Rhodospirillum salexigens. Journal of Bacteriology 106, 107-111.

Feick, R. G., FitzPatrick, M. \& FUlleR, R. C. (1982). Isolation and characterization of cytoplasmic membranes and chlorosomes from the green bacterium Chloroflexus aurantiacus. Journal of Bacteriology 150, 905-915.

Flammann, H. \& Weckesser, J. (1984). Characterization of the cell wall and outer membrane of Rhodopseudomonas capsulata. Journal of Bacteriology 159, 191-198.

Garcia, A. F. \& Drews, G. (1980). Characterization of three membrane fractions isolated from cells of Rhodopseudomonas capsulata adapting from chemotrophic to phototrophic conditions. Archives of Microbiology 127, 157-161.

Guillotin, J. \& Reiss-Husson, F. (1975). Cytoplasmic and outer membranes separation in Rhodopseudomonas sphaeroides. Archives of Microbiology 105, 269-275.

Hellingwerf, K. J., Michels, P. A. M., Dorpema, J. W. \& Konings, W. N. (1975). Transport of amino acids in membrane vesicles of Rhodopseudomonas spheroides energized by respiratory and cyclic electron flow. European Journal of Biochemistry 55, 397-406.

HoltzhaueR, M. (1989). RNS-Bestimmung mit Orcin und DNSBestimmung mit Diphenylamin. In Biochemische Labormethoden, pp. 10-11. Berlin: Springer-Verlag.

Hurlbert, R. A., Golecki, J. R. \& Drews, G. (1974). Isolation and characterization of Chromatium vinosum membranes. Archives of Microbiology 101, 169-186.

IMHOFF, J. F. (1988). Anoxygenic phototrophic bacteria. In Methods in Aquatic Bacteriology, pp. 207-240. Edited by B. Austin. Chichester: John Wiley.

IмноFF, J.F. (1991). Polar lipids and fatty acids in the genus Rhodobacter. Systematic and Applied Microbiology 14, 228-234.

IMHOFF, J. F. \& THIEMANN, B. (1991). Influence of salt concentration and temperature on the fatty acid composition of Ectothiorhodospira and other halophilic phototrophic purple bacteria. Archives of Microbiology 156, 370-375

ImHoff, J. F., SAHL, H. G., Soliman, G. S. H. \& TrüPer, H. G. (1979). The Wadi Natrun: chemical composition and microbial mass developments in alkaline brines of eutrophic desert lakes. Geomicrobiology Journal 1, 219-234.

ImHoff, J. F., Ditandy, T. \& Thiemann, B. (1991). Salt adaptation of Ectothiorhodospira. In General and Applied Aspects of Halophilic Microorganisms, pp. 115-120. Edited by F. Rodriguez-Valera. New York: Plenum Press.

Inamine, G. S., van Houten, J. \& Niederman, R. A. (1984). Intracellular localization of photosynthetic membrane growth initiation sites in Rhodopseudomonas sphaeroides. Journal of Bacteriology 158, 425-429.

Kaufmann, N., Reidl, H.-H., Golecki. J. R., Garcia, A. F. \& Drews, G. (1982). Differentiation of the membrane system in cells of Rhodopseudomonas capsulata after transition from chemotrophic to phototrophic growth conditions. Archives of Microbiology 131, 313-322.
KING, T. S. (1963). Reconstitution of respiratory chain enzyme systems. Journal of Biological Chemistry 12, 4032-4036.

KING, M. T. \& DREws, G. (1975). The respiratory electron transport system of heterotrophically-grown Rhodopseudomonas palustris. Archives of Microbiology 102, 219-231.

LAEMMLI, U. K. (1970). Cleavage of structural proteins during the assembly of the head of bacteriophage T4. Nature, London 227. $680-685$.

Lefebvre, S., Picorel, R. \& Gingras, G. (1989). Further characterization of the photoreaction center from Ectothiorhodospira spec. Detection of the $\mathrm{H}$ subunit by monoclonal antibodies. FEMS Microbiology Letters 65, 247-252.

LeguiJT, T. \& Hellingwerf, K. J. (1991). Characterization of reaction center/antenna complexes from bacteriochlorophylll $a$ containing Ectothiorhodospiraceae. Biochimica et Biophysica Acta 1057, 353360 .

Niederman, R. A. (1974). Membranes of Rhodopseudomonas spheroides: interactions of chromatophores with the cell envelope. Journal of Bacteriology 117, 19-28.

Niederman, R. A. \& Gibson, K. D. (1978). Isolation and physicochemical properties of membranes from purple photosynthetic bacteria. In The Photosynthetic Bacteria, pp. 79-118. Edited by R. K. Clayton \& W. R. Sistrom. New York: Plenum Press.

Niederman, R. A., Mallon, D. E. \& Parks, L. C. (1979). Membranes of Rhodopseudomonas sphaeroides. VI. Isolation of a fraction enriched in newly synthesized bacteriochlorophyll $a$ protein complexes. Biochimica et Biophysica Acta 555, 210-220.

Oelze, J., Golecki, J. R., Kleinig, H. \& Weckesser, J. (1975). Characterization of two cell-envelope fractions from chemotrophically grown Rhodospirillum rubrum. Antonie van Leeutenhoek 41, 273-286.

Oyewole, S. H. \& Holt, S. (1976). Structure and composition of intracytoplasmic membranes of Ectothiorhodospira mobilis. Archives of Microbiology 107, 167-182.

Picorel, R., Lu, T., Holt, R. E., Cotton, T. M. \& Seiber T, M. (1990). Surface-enhanced resonance Raman scattering spectroscopy of bacterial photosynthetic membranes: orientation of the carotenoids of Rhodobacter sphaeroides 2.4.1. Biochemistry 29, 707-712.

Reilly, P. A. \& Niederman, R. A. (1986). Role of apparent membrane growth initiation sites during photosynthetic membrane development in synchronously dividing Rhodopseudomonas sphaeroides. Journal of Bacteriology 167, 153-159.

Sahl, H. G., Großgarten, M., Widger, W. R., Cramer, W. A. \& BRANDIS, H. (1985). Structural similarities of the staphylococcin-like peptide Pep 5 to the peptide antibiotic nisin. Antimicrobial Agents and Chemotherapy 27, 836-840.

TAKEMOTO, J. \& BACHMANN, R. C. (1979). Orientation of chromatophores and spheroplast-derived membrane vesicles of Rhodopseudomonas sphaeroides: analysis by localization of enzyme activities. Archives of Biochemistry and Biophysics 195, 526-534

VANDERKoI, G. \& CAPALDI, R. (1972). A comparative study of the amino acid composition of membrane proteins and other proteins. Annals of the New York Academy of Sciences 195, 135-138. 